\title{
Effect of Filler Content on Bonding Efficacy of 4-META MMA/TBB Bonding Agent
}

\author{
Chihiro TANI, Kazuo ITOH, Hisashi HISAMITSU and Sadao WAKUMOTO \\ Department of Operative Dentistry, Showa University School of Dentistry, \\ 2-1-1 Kitasenzoku, Ohta-ward, Tokyo 145, Japan
}

Received April 8, 1994/Accepted October 19, 1994

\begin{abstract}
The effect of adding micro filler to 4-META MMA/TBB dentin bonding agent was examined by measuring the wall-to-wall polymerization contraction gap of a commercial light-cured resin composite in a cylindrical dentin cavity and the tensile bond strength of the flat dentin surface. Gap formation was not completely prevented by using a filled dentin bonding agent although the tensile bond strength was significantly greater than that obtained using the unfilled dentin bonding agent. These results indicate that the addition of micro filler to the dentin bonding agent does not produce complete adaptation of the resin composite to the dentin cavity wall.
\end{abstract}

Key words : Dentin bonding agent, Micro filler, Filler particle size, 4-META

\section{INTRODUCTION}

Dentin bonding agents are liquid resins containing a functional monomer which are applied to the dentin cavity wall after the smear layer is removed and the cavity wall is pretreated with a dentin primer. The use of liquid resin prior to filling with a resin composite was initially introduced to improve the wettability of the cavity wall, especially of an etched enamel wall, since the macro filler in the composite was larger than the enamel rod resulting in insufficient penetration of the resin composite into the micro undercut prepared by enamel etching. However, J $\phi$ rgensen and Shimokobe reported that resin tag formation was not affected by the use of an enamel bond resin ${ }^{1)}$. Such a liquid resin should be clearly distinguished from a dentin bonding agent and classified as an intermediate resin because it does not contain a functional monomer and has no effect on bonding to dentin. The efficacy of the dentin bonding agent is one of the factors which affects the marginal integrity of a resin composite restoration. Therefore, the clinical use of a dentin bonding agent is mandatory to obtain marginal adaptation in resin composite restoration.

Dentin bonding agents are characterized by the functional monomer which they contain such as methacryloxyethyl hydrogen phenyl phosphate (phenyl-P) ${ }^{2}$, methacryloxydecyl dihydrogen phosphate $(\mathrm{MDP})^{3}$, 4-methacryloxyethyl trimellitate anhydride (4-META $)^{4}$, tetra hydroxyethyl methacrylate pyrophosphate ${ }^{5)}$ or 2 (methacryloxydecyl) propane dioic acid (MAC 10) ${ }^{6}$. However, we previously reported that contraction gap formation with a commercial light-activated resin composite in a cylindrical dentin cavity could be completely prevented with only four commercial dentin bonding agents when they were combined with EDTA as a dentin cleanser and $35 \%$ glyceryl methacrylate solution as a primer ${ }^{7}$. These 
four highly effective dentin bonding agents contained some volatile components such as ethanol or MMA to dilute the functional monomer and a polymerization initiator, camphor quinone, benzoyl peroxicle and a tertiary amine such as dimethyl $\mathrm{p}$-toluidene, which produce an extremely thin bonding layer between the primed dentin cavity wall and the resin composite. However, some researchers have proposed that a dentin bonding agent containing micro filler particles or the combined use of a dentin bonding agent with a low-viscosity resin can effectively provide marginal sealing of the resin composite ${ }^{8)}$. Such a technique produces a significantly thicker than conventional treatments bonding layer between the resin composite and the dentin cavity wall. However, very little has been determined regarding the correlation between the marginal integrity of the composite and the thickness of the bonding layer.

In a previous report, we showed that contraction gap formation with a light-activated resin composite was not completely prevented using a commercial bonding agent containing micro filler particles and MDP9). The purpose of the present study was to examine the effect of filler content in the 4-META MMA/TBB dentin bonding agent on the efficacy of the dentin bonding system.

\section{MATERIALS AND METHODS}

The experimental dentin bonding agent was prepared by adding two types of micro filler particle at the proportions listed in Table 1. A commercial unfilled 4-META MMA/TBB dentin bonding agent (S.DL) and primer combination was used as a positive control. Experimental dentin bonding agents were prepared by adding micro filler in the commercial 4 -META MMA/TBB preparation. The efficacy of these commercial and experimental dentin bonding agents was examined by measuring the wall-to-wall polymerization contraction gap width of a commercial resin composite in a cylindrical dentin cavity and the tensile bond strength to a flat dentin surface.

Wall-to-wall polymerization contraction gap measurement

The proximal enamel of an extracted human molar was removed with a wet carborundum paper (grit 220) and a cylindrical cavity, approximately $3 \mathrm{~mm}$ in diameter and $1.5 \mathrm{~mm}$ deep, was prepared in the exposed dentin. The cavity wall was cleaned with a neutralized $0.5 \mathrm{M}$

Table 1 The dentin bonding agents tested

\begin{tabular}{|c|c|c|c|}
\hline Code & Filler Particle Size & Filler Content & Lot No. \\
\hline SDL@ & $0 \quad(\mu \mathrm{m})$ & $0(w t \%)$ & Liquid 30802 , Catalyst 307101 \\
\hline $\mathrm{R}-972-3$ & 0.014 & 3 & experimental \\
\hline$R-972-5$ & 0.014 & 5 & experimental \\
\hline $\mathrm{R}-972-7.5$ & 0.014 & 7.5 & experimental \\
\hline $\mathrm{RM}-50-7$ & 0.040 & 7 & experimental \\
\hline RM-50-10 & 0.040 & 10 & experimental \\
\hline RM-50-15 & 0.040 & 15 & experimental \\
\hline CLB 2@@ & unknown & $13.14 \pm 0.12$ & 0007 \\
\hline
\end{tabular}

@ Dentin bonding aggent; Superbond D-Liner system (Sun Medical, Shiga, Japan).

@@ Dentin bonding aggent; Clearfil Liner Bond 2 system (Kuraray, Osaka, Japan). 
EDTA solution ( $\mathrm{pH}$ 7.4) for $60 \mathrm{sec}$ followed by a water spray and an air blast. The cavity was then treated with an experimental dentin primer composed of 35 vol \% glyceryl methacrylate $(\mathrm{GM}) *$ solution for $30 \mathrm{sec}$, and the cavity was dried completely. One of the dentin bonding agents was then applied to the cavity which was then slightly over-filled with a light-activated resin composite**. The surface of the composite was covered with a plastic matrix and momentarily pressed flat on to a glass plate and irradiated for $40 \mathrm{sec}$ using a commercial lamp unit\#. The light-cured dentin bonding agent (CLB 2) was irradiated for $20 \mathrm{sec}$ before filling with resin composite.

After storing the specimens in water for $10 \mathrm{~min}$, the cavity margin was exposed with wet carborundum paper (grit 1000) and polished on a linen-mediated alumina slurry (grain size 0.3 $\mu \mathrm{m})$. Marginal integrity was examined under a light microscope and any gap width was measured at eight points every 45 degrees along the cavity margin using a screw micrometer\#\# mounted on an ocular lens. The maximum contraction gap was presented as the sum of the opposing gap widths as a percentage of the cavity diameter. Ten specimens were prepared for each dentin bonding agent (80 in total).

\section{Tensile bond strength measurement}

A flat dentin surface was prepared on an extracted human tooth embedded in epoxy resin ${ }^{\circledR}$ with wet carborundum paper (grid number 1000) at the final stage. The dentin surface was cleaned and primed as described above and a split Teflon mold with an inner diameter of 3.6 $\mathrm{mm}$, outer diameter of $20 \mathrm{~mm}$ and height of $8 \mathrm{~mm}$, was fixed on the substrate. The dentin bonding agent was then applied to the dentin through the cylindrical hole in the ring-like mold. The resin composite was added at a thickness of not more than $2 \mathrm{~mm}$ and irradiated for $40 \mathrm{sec}$. Finally, the remaining space in the mold above the resin composite was filled with a chemically cured resin composite ${ }^{\circledR}$ and a round bur was inserted into the composite to provide a grip to measure tensile bond strength. After storing the specimens in water for 24 hours, tensile bond strength was measured using a universal testing machine ${ }^{\$}$ with a cross -head speed of $5 \mathrm{~mm} / \mathrm{min}$. Ten specimens were measured for each group (80 in total).

Measurement of the filler content in the commercial dentin bonding agent

The filler content of the commercial dentin bonding agent (CLB 2) was measured according to the ISO No. 4049-1978. A crucible was heated in a furnace at a temperature of $580^{\circ} \mathrm{C}$ for $15 \mathrm{~min}$, then cooled in a desiccator and weighed. Approximately $0.5 \mathrm{~g}$ of the commercial dentin bonding agent (CLB 2) was weighed in the crucible and heated in the furnace at $580{ }^{\circ} \mathrm{C}$ for $30 \mathrm{~min}$. The filler content in the dentin bonding agent was calculated as the percentage of the weight after heating to that before heating. The measurement was repeated three times and the mean value was presented as the filler content.

\footnotetext{
* Blemmer GLM, Nippon Oil and Fat, Tokyo, Japan

* * Silux Plus, 3M, St. Paul, MN, USA

\# Wite Light, Takara Belmond, Osaka, Japan

\# Eyepiece Digital, Leitz, Wetzlar, W. Germany

@ Epofix Resin, Struers, Copenhagen, Denmark

@ @ P-10, 3M, St. Paul, MN, USA

\$ Model 4302, Instron, Boston, Mass, USA
} 


\section{RESULTS}

The mean filler content of the commercial dual-cured dentin bonding agent was $13.144 \mathrm{wt} \%$. However, marginal adaptation of the composite was not complete in four of 10 specimens.

The results of the contraction gap measurement are presented in Table 2. Marginal integrity was complete only in the positive control group (SDL), in which a commercial unfilled dentin bonding agent was employed. In the experimental dentin bonding groups, a contraction gap was observed in one to four of the 10 specimens. Furthermore, the filled dentin bonding agent was significantly thick and the film thickness was not uniform along the cavity margin (Fig. 1 and Fig. 2). In contrast, the unfilled bonding agent was too thin to be detected under the light microscope (Fig. 3).

The unfilled bonding agent showed significantly lower tensile bond strength than the filled bonding agents (Table 2).

As mentioned above, the addition of filler to the bonding agent formed a thick layer between the resin composite and the dentin cavity wall, which resulted in higher tensile bond strength and incomplete marginal integrity of the resin composite in the cylindrical dentin cavity.

\section{DISCUSSION}

Liquid resins mediating between the resin composite and the cavity wall were first introduced to improve the wettability of the etched enamel surfaces. However, they had no effect on dentin bonding because they were composed of resin materials which were similar to the base

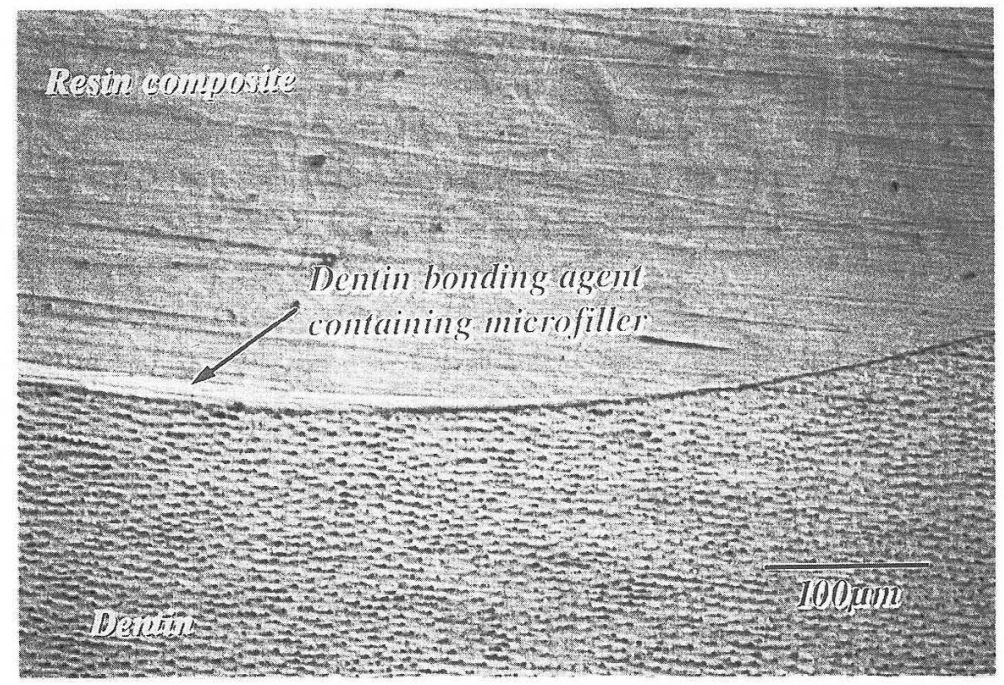

Fig. 1 Marginal adaptation of Silux Plus in the dentin cavity cleaned with EDTA, primed with GM solution and mediated with an experimental dentin bonding agent containing micro filler at a proportion of 7.5 wt $\%$. The thickness of the dentin bonding agent layer was not uniform along the cavity margin. 


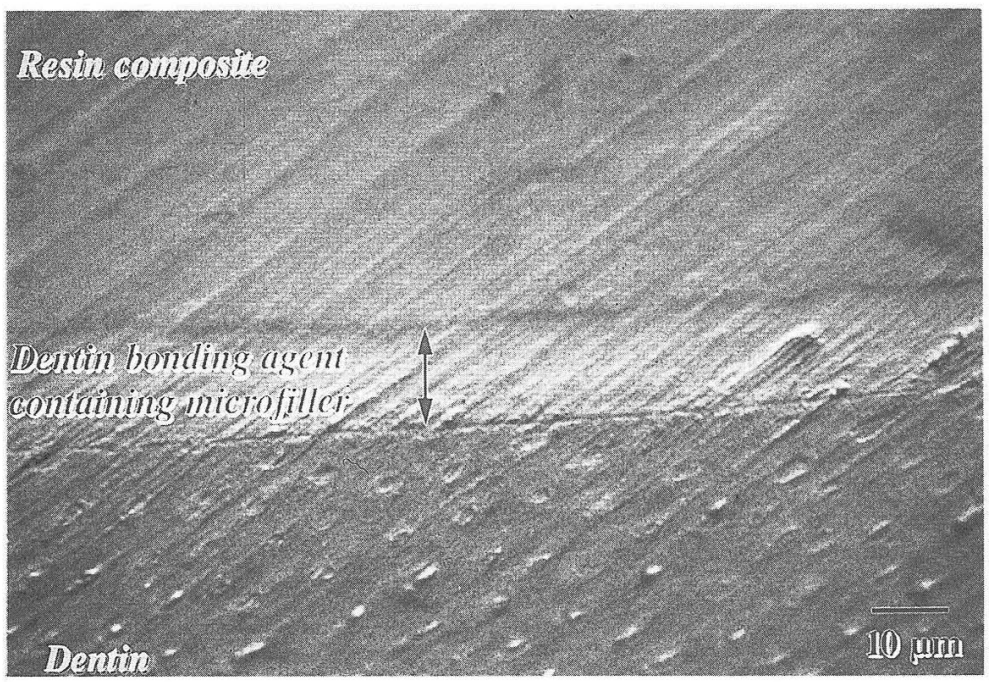

Fig. 2 Higher magnification of Fig. 1. The bonding agent layer was significantly thicker than that of the unfilled bonding agent (Fig. 3).

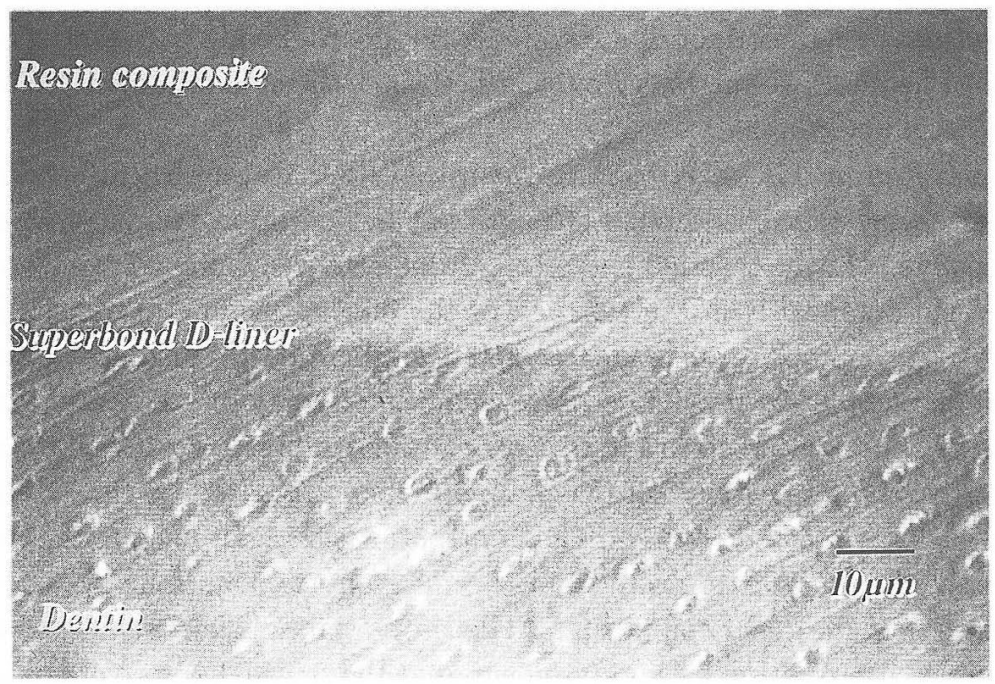

Fig. 3 Adaptation of Silux Plus to the dentin cavity margin cleaned with EDTA and primed with GM solution. A commercial unfilled dentin bonding agent (Superbond Dliner) was applied prior to composite filling. The film of unfilled dentin bonding agent was too thin to be detected under the light microscope.

resin matrix of the composite: Bis-GMA, triethyleneglycol dimethacrylate or hydroxyethyl methacrylate. Such resins laching any functional monomers should be classified as interme diate resins and distinguished from dentin bonding agents.

Not only the Phenyl-P but also 4-META, MDP, MAC 10, tetramethacryloxyethyl hydrogen pyrophosphate and 4-acryloxyethyl trimellitate anhydride have been reported to be 
Table 2 Efficacy of the dentin bonding agents tested

\begin{tabular}{lcc}
\hline Code & Contraction Gap (\%)* & Tensile Bond Strength (MPa) \\
\hline SDL & $0(10)(0)$ & $12.21 \pm 4.67$ \\
R-972-3 & $0.014(8)(0-0.075)$ & $19.80 \pm 4.24$ \\
R-972-5 & $0.005(9)(0-0.049)$ & $18.33 \pm 4.30$ \\
R-972-7.5 & $0.009(9)(0-0.091)$ & $17.42 \pm 4.52$ \\
RM-50-7 & $0.026(6)(0-0.096)$ & $16.52 \pm 3.32$ \\
RM-50-10 & $0.009(9)(0-0.087)$ & $20.56 \pm 6.01$ \\
RM-50-15 & $0.018(8)(0-0.117)$ & $14.40 \pm 6.23$ \\
CLB 2 & $0.025(6)(0-0.090)$ & $16.26 \pm 3.01$
\end{tabular} \mid

* Mean value of the contraction gap, number of gap-free specimens (in a total of 10) and range of gap values.

* * Values joined by a line are not significantly different. Dentin surfaces were cleaned with neutralized $0.5 \mathrm{M}$ EDTA and primed with 35 wt \% glyceryl methacrylate solution before dentin bonding agent application followed by resin composite placing.

effective as functional monomers, and various dentin bonding agents characterized by these monomers have been rnarketed. Furthermore, a micro particle-filled bonding agent was recently developed to promote the efficacy of the dentin bonding system although we previously reported that the effect of the commercial dentin bonding system composed of self etching primer, Phenyl-P, N-methacryloyl 5-amino salicylic acid diluted in HEMA, and filled bonding agent was not complete.

As demonstrated in this study, adding the micro filler to the dentin bonding agent was effective in increasing the tensile bond strength but not on improve marginal adaptation of the resin composite. In the tensile bond strength measurement, the influence of contraction stress of the resin composite on the efficacy of the dentin bonding system is impossible to detect because the composite shrinks towards the flat dentin surface. Contraction gap formation can be completely prevented only when the efficacy of the dentin bonding system overcomes the polymerization contraction stress of the composite during polymerization, and when the contraction of the composite is completely compensated by flow of the composite from the free surface into the cavity. The contraction gap width should be measured with in a short period after resin composite filling because any contraction gap may be closed by the water sorption of the resin composite. Therefore, gap measurement was performed 10 min after specimen preparation in this study, whereas the tensile bond strength was measured after 24 hours. We reported that the tensile bond strength of the experimental dentin bonding system compcsed of EDTA cleaning, GM priming and a commercially available dentin bonding agent was not affected significantly by the storage time of the specimens in water from $10 \mathrm{~min}$ up to 24 hours. It is inconsistent, however, to estimate the correlation between tensile bond strength and the contraction gap value of the bonding system because the dentin bonding agent should polymerize quickly over an extremely short period at the early stage of polymerization of the resin composite to prevent contraction gap formation. The filler particles in the dentin bonding agent may inhibit bonding between the resin composite and dentin during polymerization of the composite because a filled dentin bonding agent shows a significantly higher viscosity, thus disturbing the diffusion of monomer into the 
dentin or interfering with quick polymerization of the dentin bonding agent. Furthermore, the high tensile bond strength of a filled bonding agent, as compared with that of the unfilled bonding agent, might be a result of improved mechanical strength of the bonding layer. However, the adhesion between resin composite and dentin, as altermined by contraction gap measurement, is representative of tensile bond strength between parallel cavity walls, and is useful for marginal adaptation to contraction gap measurement.

Previously, we proposed ${ }^{10)}$ that consistent bonding efficacy should be measured primarily in terms of contraction gap formation to ensure that bonding between the dentin cavity margin and resin composite was established. If the bonding system was then ensured to be contraction gap-free, then the tensile bond strength should be measured after long-term storage of the specimen to estimate the bonding stability or longevity of the gap-free system. The present results indicated that adding micro filler to the dentin bonding agent and the formation of a thick bonding layer should be avoided because a contraction gap was formed between the light-cured resin composite and the dentin cavity margin, which indicated that bonding was not established just after composite polymerization.

\section{REFERENCES}

1) J $\phi$ rgensen, K. D. and Shimokobe, H. : Adaptation of resinous restorative materials to acid etched enamel surfaces, Scand J Dent Res 83: 31-36, 1975.

2) Watanabe, I. : Photocure bonding agents to ground to dentin, J J Dent Mater 11 (6) : 955-973, 1992. (in Japanese)

3) Yamauchi, J., Nakabayashi, N. and Masuhara, E.: Adhesive agents for hard tissue containing phosphoric acid monomers, ACS Polymer Preprints 20 (1): 594-595, 1979.

4) Takeyama, M., Kashibuchi, S., Nakabayashi, N. and Masuhara, E.: Studies on dental self-curing resins (17)-Adhesion of PMMA with bovine enamel or dental alloys, J. Japan Soc Dent Appar Mat 19 (47) : 179-185, 1978. (in Japanese)

5) Manabe, A., Itoh, K. and Wakumoto, S.: The optimum combination of bonding systems, Dent Mater 7: 145-147, 1991.

6) Kawaguchi, T., Kunimoto, S., Iwamoto, O. and Kusumoto, K.: Adhesion of new bonding agent MB to dentin, $J$ J Dent Mater 7 (special issue 12) : 10-11, 1988. (in Japanese)

7) Chigira, H., Itoh, K. and Wakumoto, S.: Marginal adaptation of nine commercial intermediate resin, Dent Mater 7 : 103-106, 1991.

8) Hosoda, H.: Dentin bonding-Personal view and it's materialization, J Stomatol Soc Jpn 60 (2): 249 -256, 1993. (in Japanese)

9) Tani, C., Itoh, K., Hisamitsu, H. and Wakumoto, S. : Efficacy of dentin bonding agents combined with Self-etching dentin primers containing Phenyl-P, Dent Mater J 12 (2) : 219-224, 1993.

10) Takemori, T., Chigira, H., Itoh, C., Hisamitsu, H. and Wakumoto, S. : Factors affecting tensile bond strength of composite to dentin, Dent Mater 8: 136-138, 1993. 


\title{
本号掲載論文の和文抄録
}

\author{
ボンディング材へのフィラーの混入が，象牙質接着性に及ぼす影響について \\ 谷 千尋, 伊藤和雄, 久光 久, 和久本貞雄 \\ 昭和大学歯学部歯科保存学第 2 講座
}

\begin{abstract}
マイクロフィラーを混入した4-META MMA/TBB 系デンチンボンディング材を試作し，その象牙質接着性 能をヒト抜去歯象牙質内に形成した円柱窩洞に填塞され た市販可視光線重合型コンポジットレジンの象牙質窩壁 適合性と象牙質平面に対する引張り接着性試験により検 討した. その結果, フィラーを混入していないデンチン ボンディング材を用いた場合には, 完全な象牙質窩壁適 合性が得られたが, フィラーを混入した場合には,すべ ての試片で完全な象牙質窩壁適合性が観測されるとは限
\end{abstract}

らなかった. しかしながら, 引張り接着力試験では, フ

ィラーの混入によって有意に計測値は上昇した. すなわ ち，デンチンポンディンク゚材にフィラーを配合すること により象牙質接着強さは向上するものの, 象牙質窩壁と コンポジットレジンとの間に形成されるコントラクショ ンギャップを, 完全には抑制することは出来なくなり, コンポジットレジン修復用デンチンボンディング材にフ イラーを配合する有効性は否定された.

\section{ガラス質陶材の強さに及ぼすリューサイト結晶の影響 \\ 今 政幸, 河野文昭 ${ }^{1}$, 浅岡憲三, 松本直之 ${ }^{1}$ \\ 徳島大学歯学部歯科理工学講座 \\ 1徳島大学歯学部歯科補経学第一講座}

\begin{abstract}
熱膨張係数の大きいリューサイト結晶を含有する陶材 の強さに及ぽすリューサイト結晶の挙動について検討す ることを目的とした.このため, 熱膨張係数, 組成およ び軟化温度の異なる 3 種のガラスマトリックスを使用し てリューサイト結晶粒子を分散したガラス質陶材を作製 した. その結果, リューサイトを含有する陶材の強さは ガラスマトリックスの組成, 熱膨張係数および軟化温度 の違いに影響されることがわかった. 特に膨張係数のミ スマッチの大きいホウケイ酸ガラスをマトリックスに用
\end{abstract}

いた場合はリューサイト含有量の増加につれて強さは低 下した．また長石質ガラスの場合は強さに殆ど変化がみ られなかった. しかし, ソーダ石灰ガラスを使用した場 合はリューサイトを添加することによりガラス単独のも のに比較して, 強化されることがわかった. 強さが向上 した原因はリューサイト粒子がガラス相へ溶け込むこと により，リューサイト粒子とガラス相の界面が連続相と なるためであると考えられた。 